\title{
Article III Implications for the Applicability of the Seventh Amendment to Federal Statutory Actions
}

\author{
Colleen P. Murphy
}

The Supreme Court's analysis of the applicability of the Seventh Amendment ${ }^{1}$ to federal statutory actions ${ }^{2}$ has been inconsistent and doctrinally misguided. In an Article III trial court, the right to a civil jury trial in a federal statutory action depends upon whether the action is legal or equitable in nature; only legal actions are jury triable of right under the Seventh Amendment. ${ }^{3}$ By contrast, in a non-Article III federal forum, ${ }^{4}$

1. The Seventh Amendment states:

In Suits at common law, where the value in controversy shall exceed twenty dollars, the right of trial by jury shall be preserved, and no fact tried by a jury, shall be otherwise reexamined in any Court of the United States, than according to the rules of the common law. U.S. ConsT. amend. VII. The right to a jury trial in a civil proceeding operates only if demanded by a party, Fed. R. Crv. P. 38(b), or if ordered by a court in its discretion, FED. R. CIv. P. 39(b).

2. Unless otherwise indicated, "statutory actions" refer to civil actions based on substantive rights and duties created by Congress, distinct from traditional common law and equity actions that have evolved in the courts. Congress has created numerous substantive rights and duties. See, e.g., Age Discrimination in Employment Act of 1967, 29 U.S.C. $\$ 626(c)(1)$ (1982) (conferring right to sue for arbitrary age discrimination in employment); Toxic Substances Control Act, 15 U.S.C. $\$ \$ 2601-2629$ (1982) (regulating chemical substances and mixtures). Reference herein to statutes creating substantive rights and duties does not include jurisdictional statutes or purely remedial statutes such as 42 U.S.C. $\S 1983$ (1982), which is "not itself a source of substantive rights, but a method for vindicating federal rights elsewhere conferred." Baker v. McCollan, 443 U.S. 137, 144 n.3 (1979).

3. See, e.g., Curtis v. Loether, 415 U.S. 189 (1974) (Seventh Amendment applies to actions under fair housing provisions of Civil Rights Act of 1968 because actions are legal in nature); Pernell v. Southall Realty, 416 U.S. 363 (1974) (party has right to jury trial in action brought under District of Columbia statute establishing procedure for recovery of real property because statute provides traditional form of legal relief); see also infra note 13.

4. Throughout this Note, the terms "non-Article III forums" or "non-Article III tribunals" refer not to state courts, but to federal adjudicatory bodies such as legislative courts and administrative agencies, whose judges do not have the tenure and salary guarantees of Article III.

Legislative courts are also referred to as Article I courts because Congress generally creates such tribunals pursuant to one of its enumerated powers in Article I, $\$ 8$. Legislative courts currently in existence include territorial courts, military tribunals, local courts of the District of Columbia, and the U.S. Tax Court. See generally 13 C. WRight, A. Miller \& E. CoOper, Federal. Practice and PROCEDURE \$ 3528, at 262-64 (1984) (noting categories of legislative courts).

It is debatable whether legislative courts are constitutionally distinguishable from administrative agencies. Compare Redish, Legislative Courts, Administrative Agencies, and the Northern Pipeline Decision, 1983 DUKE L.J. 197, 201 (arguing that "the Court cannot logically distinguish the work of non-article III legislative courts from that of administrative adjudicatory bodies") and Glidden Co. v. Zdanok, 370 U.S. 530, 549 (1962) (plurality opinion) (equating legislative courts with administrative agencies) with Note, Article III Limits on Article I Courts: The Constitutionality of the Bankruptcy Court and the 1979 Magistrate Act, 80 Colum. L. REv. 560, 579-80 (1980) (arguing that administrative agencies differ from legislative courts because their decisions are reviewable in Article III courts and their coercive orders are enforceable only with aid of Article III courts). 
such as an administrative adjudicatory tribunal, the question whether the statutory action is legal or equitable in nature is irrelevant-the Seventh Amendment simply does not apply.

The Supreme Court should resolve this doctrinal discrepancy by recognizing that in both Article III courts and non-Article III adjudicatory forums, statutory actions are not suits at common law and thus fall outside the scope of the Seventh Amendment. ${ }^{6}$ Unless Congress explicitly confers a right to jury trial in causes of action it has created, federal statutory actions should be tried without juries.

\section{The Forum-Dependent Nature of Seventh Amendment DOCTRINE}

In determining whether civil statutory actions in federal forums ${ }^{7}$ are jury triable of right, the Supreme Court alters its analysis according to the type of forum adjudicating the action. The practical result of the Court's forum-dependent interpretation of the Seventh Amendment is that determinations of the right to jury trial in statutory actions are based more on the federal forum adjudicating an action than the nature of the action itself.

\section{A. Statutory Actions in the Federal District Courts}

Analysis of the Seventh Amendment's applicability to federal statutory actions requires consideration of the extent to which Article III and the

Since the argument here relies on Supreme Court statements that factfinding in actions based on congressionally created rights need not occur in Article III courts, see infra notes 42-72 and accompanying text, any arguable distinction between legislative courts and administrative tribunals based on Article III is irrelevant.

5. The Supreme Court has upheld adjudications in non-Article III tribunals against Seventh Amendment challenge. See, e.g., Atlas Roofing Co. v. Oocupational Safety \& Health Review Comm'n, 430 U.S. 442, 449-61 (1977) (action for civil penalties before Occupational Safety and Health Review Commission not jury triable of right); NLRB v. Jones \& Laughlin Steel Corp., 301 U.S. 1, 48-49 (1937) (Seventh Amendment does not apply to suit for backpay before National Labor Relations Board).

6. Implicit in this argument is the assumption that the "nature of the action" should be the sole determinant of the right to jury trial, regardless of the forum. See infra text accompanying note 40.

7. The Seventh Amendment does not bind state courts. See Walker v. Sauvinet, 92 U.S. 90, 92-93 (1876) (Seventh Amendment not made applicable to states through Fourteenth Amendment).

It is irrelevant to the argument proposed here that state courts may provide a forum for the adjudication of federal statutory actions, see generally Amar, A Neo-Federalist View of Article 1II: Separating the Two Tiers of Federal Jurisdiction, 65 B.U.L. REv. 205 (1985) (arguing state courts may generally entertain federal question cases, subject to review by Article III courts), and in doing so, sit without juries. The Supreme Court has not treated state courts and non-Article III federal tribunals similarly with respect to the matters that may constitutionally be assigned to each. See, e.g., Northern Pipeline Constr. Co. v. Marathon Pipe Line Co., 458 U.S. 50, 63-87 (1982) (although state courts may adjudicate contract claims relating to bankruptcy proceedings, non-Article III tribunals may not). Consequently, Article III and Seventh Amendment jurisprudence regarding adjudication by nonArticle III tribunals informs the question whether federal statutory actions in Article III courts are jury triable of right. 
Seventh Amendment converge. Article III extends the judicial power of the United States to "all Cases, in Law and Equity;"8 the Seventh Amendment preserves the right to jury trial in "Suits at common law."

In the early nineteenth century, Justice Story assumed that the term "common law" in the Seventh Amendment was synonymous with the term "law" in Article III, ${ }^{10}$ and thus that the amendment "embrace[d] all suits ... not of equity and admiralty jurisdiction."11 Accepting Story's interpretation of the Seventh Amendment, the Supreme Court has treated Article III's grant of federal jurisdiction over "all cases in law and equity" as implying that civil suits in the district courts are either suits at common law or suits in equity. ${ }^{12}$ Consequently, in determining whether there is a right to jury trial in a given action, the courts have focused on whether the action is legal or equitable in nature. ${ }^{13}$

In suits based on statutory rights, this analysis triggers the Seventh Amendment "if the action involves rights and remedies of the sort typically enforced in an action at law."14 In Curtis v. Loether ${ }^{15}$ and Pernell v. Southall Realty, ${ }^{16}$ the Court held that the Seventh Amendment applies to actions enforcing statutory rights, ${ }^{17}$ analogizing the statutory rights and

8. U.S. Const. art. III, § 2.

9. See supra note 1.

10. "By common law, [the Framers] meant what the constitution denominated in the third article 'law' . ..." Parsons v. Bedford, 28 U.S. (3 Pet.) 433, 447 (1830) (emphasis in original).

11. Id.

12. The Supreme Court has recognized a third category of civil action-composed of proceedings based on statutes-only in the context of non-Article III tribunals. This recognition has produced a forum-dependent interpretation of the Seventh Amendment in which the identical action may be termed a common law suit in an Article III court but a statutory proceeding in a non-Article III forum. See infra notes 31-32 and accompanying text.

13. Prior to 1938, when the Federal Rules of Civil Procedure merged law and equity, the Seventh Amendment afforded a right to trial by jury only when a federal court sat in "law." When a federal court sat in "equity" (or "admiralty"), there was no right to a jury trial. Under this approach, the grant of a jury trial depended upon whether the action was conducted according to procedures at common law or in equity. When the Federal Rules abolished separate law and equity procedures, the traditional basis for determining the right to jury trial-looking at the pleadings-disappeared. See F. James \& G. Hazard, Civil Procedure \$ 8.4, at 424 (3d ed. 1985).

With merged procedures, the Supreme Court adopted a different test for the civil jury right: If the "nature of the issue to be tried" in a civil action is legal, the Seventh Amendment guarantees a jury trial. If the nature of the issue is equitable, no constitutional right to a jury trial exists. See Ross v. Bernhard, 396 U.S. 531, 538-42 (1970) (underlying substantive corporate claim in shareholder's derivative action legal in nature, even though derivative action historically equitable); Dairy Queen, Inc. v. Wood, 369 U.S. 469, 470-473 (1962) (litigant entitled to jury trial even though legal issues "incidental" to primary equitable claim); Beacon Theatres, Inc. v. Westover, 359 U.S. 500, 503-11 (1959) (Seventh Amendment guarantees right to jury trial of antitrust counterclaim because remedy requested "legal" in nature).

14. Curtis v. Loether, 415 U.S. 189, 195 (1974) (footnote omitted).

15. 415 U.S. 189 (1974).

16. 416 U.S. 363 (1974).

17. Curtis involved section 812 of Title VIII of the Civil Rights Act of 1968, enabling private plaintiffs to sue on violations of fair housing provisions. 42 U.S.C. $\$ 3612$ (1982). Pernell addressed a District of Columbia statute, D.C. CoDE $\$ \S 16-1501$, to -1505 (1981 \& Supp. 1985), establishing a procedure for the recovery of possession of real property. 
remedies involved in those cases to rights and remedies known at common law. ${ }^{18}$ Judicial attempts to force statutory actions into legal or equitable categories have, however, produced an unpredictable interpretation of the Seventh Amendment from case to case. ${ }^{19}$

18. The Curtis Court agreed with the lower court's conclusion that Title VIII provides a cause of action analogous to a number of common law tort actions, such as breach of the common law duty of innkeepers not to refuse a traveler temporary lodging without justification, and the common law actions for defamation or intentional infliction of mental distress. 415 U.S. at 195 n.10. More important to the jury trial issue, the Court stressed, was the fact that the remedy sought-actual and punitive damages-was relief traditionally obtained in courts of law. Id. at 196.

In Pernell, the plaintiff sought eviction rather than money damages. The Court acknowledged that the statutory procedure at issue had no common law analogue, but concluded that the procedure served the same essential function-permitting a plaintiff to evict one who is wrongfully detaining possession and to regain possession himself-as the common law action of ejectment. 416 U.S. at 375. Common law ejectment was an action to try the title to real property. See T. PluckneTt, A Concise History of THE COMMON LAw 374 (5th ed. 1956). The plaintiff in Pernell, however, sought eviction for nonpayment of rent; title was not at issue. Thus, the Court found a right to jury trial not because the statutory cause of action was analogous to one existing at common law, but rather because the relief made available by the statute was the same relief afforded by a common law action. 416 U.S. at 375 .

Curtis and Pernell illustrate that the "nature of the issue" inquiry, when applied to statutory actions in Article III courts, often translates into a focus on the available remedies. The remedy in administrative adjudications, however, is not a relevant factor in determining the applicability of the Seventh Amendment. For example, in Atlas Roofing Co. v. Occupational Safety \& Health Review Comm'n, 430 U.S. 442 (1977), the Court found that the defendant in a statutory action was not entitled to a jury trial, even though the federal government as plaintiff sought a money judgment-traditionally a common law remedy. The Court's inconsistent treatment of remedies typifies the flaws in current interpretation of the Seventh Amendment's applicability to federal statutory actions.

19. Pernell exemplifies the analytical difficulties that arise in a situation where no common law analogue to the statutory action exists and where the plaintiff does not seek damages. See supra note 18.

If monetary remedies are provided by statute, current doctrine dictates characterization of such remedies as either damages or restitution, because the distinction between the two historically afforded a means to differentiate law from equity. See Porter v. Warner Holding Co., 328 U.S. 395, 402 (1945) (noting that restitution lies within court's equitable jurisdiction). Because this distinction is often subtle, characterizations of monetary remedies have been inconsistent. For example, the Court has concluded that because Congress explicitly provided that violations of Title VIII of the 1968 Civil Rights Act could be redressed through actual and punitive damages, see 42 U.S.C. $\$ 3612$ (1982), a claim under the statute for monetary relief was "legal" in nature and thus jury triable of right. Curtis v. Loether, 415 U.S. at 195 . Conversely, the Court has noted in dictum that although Title VII of the Civil Rights Act of 1964, as amended by the Equal Opportunity Act of 1972, authorizes plaintiffs to request monetary relief in the form of backpay, see 42 U.S.C. $\$ \S 2000 \mathrm{e}-5(\mathrm{~g})(1982)$, the statutory remedy is equitable. Great American Federal Savings \& Loan v. Novotny, 442 U.S. 366, 375 (1979).

Whether a monetary remedy provides legal or equitable relief cannot simply be determined from a superficial reading of statutory language, however. In Lorillard v. Pons, 434 U.S. 575 (1978), for example, the Court found that a claim for backpay authorized by the Age Discrimination in Employment Act of 1967 (ADEA), 29 U.S.C. $\$ 633 \mathrm{a}$ (c) (1982), was jury triable of right. Yet, backpay had been declared an equitable remedy in Novotny. The Court stressed that Title VII provides only equitable relief, whereas the ADEA provides "for both "legal or equitable relief." 434 U.S. at 584. Although the Court in Lorillard focused on the term "legal" in concluding that a claim for backpay under the ADEA is jury triable of right, it construed the same statute less literally in Lehman v. Nakshian, 453 U.S. 156 (1981) (no right to jury trial in ADEA suits against federal government), remarking that "no particular significance can be attributed to the word 'legal" "where the federal government is a defendant. Id. at 163. 


\section{B. Statutory Actions in Non-Article III Federal Tribunals}

When Congress has assigned factfinding in statutory actions to administrative tribunals, ${ }^{20}$ the Supreme Court has not focused on whether the nature of the action is legal or equitable. Rather, the Court has simply declared the Seventh Amendment inapplicable to actions in administrative tribunals. $^{21}$

In Atlas Roofing Co. v. Occupational Safety and Health Review Commission, ${ }^{22}$ the Supreme Court unanimously ${ }^{23}$ held that government imposition of monetary penalties in an administrative adjudication without jury trial does not violate the Seventh Amendment. ${ }^{24}$ The Atlas Roofing Court cited several decisions sustaining similar statutory schemes against Article III and due process challenges. ${ }^{25}$ Acknowledging that these decisions did

20. Most frequently, judicial review of administrative adjudications is placed in the federal courts of appeals and limited to questions of law. See J. MAShaw \& R. MERriLl, ADMinistrative Law 250 (2d ed. 1985). Thus, in rendering final factual determinations for which there is no de novo review by Article III courts, administrative agencies "perform much the same functions with respect to the courts of appeals as do the district courts." 16 C. WRIGHT, A. Miller, E. COOPER, \& E. Gressman, Federal Practice and Procedure § 3940, at 302 (1977).

Although administrative factinding is generally conclusive, it may be set aside by the reviewing court if "unsupported by substantial evidence." See Administrative Procedure Act (APA) $§ 706(2)(E)$, 5 U.S.C. $\S 706(2)(E)$ (1982). The APA's "substantial evidence" standard can be supplanted by specific judicial review provisions in an agency's organic statute. See J. Mashaw \& R. MERRILL, supra, at 322.

21. See Atlas Roofing Co. v. Occupational Safety \& Health Review Comm'n, 430 U.S. 442,460 (1977) ("We cannot conclude that the [Seventh] Amendment rendered Congress powerless . . . to create new public rights and remedies by statute and commit their enforcement, if it chose, to a tribunal other than a court of law-such as an administrative agency-in which facts are not found by juries."); Curtis v. Locther, 415 U.S. 189, 195 (1974) ("These cases uphold congressional power to entrust enforcement of statutory rights to an administrative process . . . free from the strictures of the Seventh Amendment."); Pernell v. Southall Realty, 416 U.S. 363, 383 (1974) ("[T]he Seventh Amendment is generally inapplicable in administrative proceedings, where jury trials would be incompatible with the whole concept of administrative adjudication.") (citing Curtis, 415 U.S. at 194).

The exception to this rule is Katchen v. Landy, 382 U.S. 323 (1966), where the Court rejected a Seventh Amendment challenge to proceedings in the bankruptcy courts by declaring that such proceedings are inherently equitable. Id. at 337. The plurality opinion in Northern Pipeline Constr. Co. v. Marathon Pipe Line Co., 458 U.S. 50 (1982), however, hinted that Katchen may no longer be good law, because it did not address whether the bankruptcy courts conformed with Article III requirements. Id. at 79 n.31.

22. 430 U.S. 442 (1977).

23. Justice Blackmun did not participate in the decision. Id. at 443.

24. Atlas Roofing upheld portions of the Occupational Safety and Health Act, 29 U.S.C. $\$ \$ 659$, 666 (1982), that empower the federal government to seek money penalties before the Occupational Health and Safety Commission for violation of the employer's duty to maintain safe and healthy working conditions. No jury trial is available in OSHA adjudications. 430 U.S. at 447.

25. See Atlas Roofing, 430 U.S. at 456 , where the Court cited (in order of mention) Lloyd Sabaudo Societa v. Elting, 287 U.S. 329 (1932) (due process does not require judicial trial of government claims under immigration statute); Oceanic Navigation Co. v. Stranahan, 214 U.S. 320 (1909) (same); Murray's Lessee v. Hoboken Land Co., 59 U.S. (18 How.) 272 (1856) (Article III and Fifth Amendment due process clause not violated when administrative body audited customs collector's accounts and issued warrant); Phillips v. Commissioner, 283 U.S. 589 (1931) (collection of internal revenue by summary administrative proceedings not violative of due process). The Court also cited Helvering v. Mitchell, 303 U.S. 391 (1938), which rejected a double jeopardy claim in upholding the power of the Commission of Internal Revenue to assess tax penalties. 
not expressly refer to the Seventh Amendment, the Court nevertheless found it "difficult to believe that these holdings or dicta did not subsume the proposition that a jury trial was not required."26 The Court thus assumed that if litigants in statutory actions are not entitled to trial in an Article III court, they are not entitled to factfinding by a jury in an administrative proceeding.

Ostensibly limiting its holding to cases in which the federal government sues to enforce new statutory "public rights," nonetheless briefly recognized that an administrative tribunal could perform the factfinding function in cases involving "private rights" ${ }^{28}$ as well, although "only as an adjunct to an Art[icle] III court." statutory actions, involving either public or private rights, administrative tribunals are constitutionally permitted to displace juries from their only function-factfinding. ${ }^{30}$

\section{The Illogic of a Forum-Dependent Approach to the Seventh Amendment}

Current Supreme Gourt doctrine suggests that the constitutional right to a civil jury trial depends in part on the forum in which a statutory action is litigated. Identical claims can thus be subject to varying procedural formats. In Atlas Roofing, Curtis, and Pernell, the Court has indi-

26. 430 U.S. at 456 .

27. The Court stated that the Seventh Amendment did not prohibit administrative adjudication of "cases in which 'public rights' are being litigated-e.g., cases in which the Government sues in its sovereign capacity to enforce public rights created by statutes within the power of Congress to enact." $I d$. at 450 . For a discussion of the various definitions given "public rights," see infra notes $45-47$ and accompanying text.

28. In discussing administrative factfinding in cases involving "private rights," Atlas Roofing cited Crowell v. Benson, 285 U.S. 22, 51-65 (1932). See 430 U.S. at 450 n.7. The Crowell Court defined a private rights case as one addressing the "liability of one individual to another under the law as defined." 285 U.S. at 51.

29. 430 U.S. at 450 n.7. Atlas Roofing cited Crowell for the proposition that in private rights cases, "this Court has accepted factfinding by an administrative agency, without intervention by a jury, only as an adjunct to an Art. III court, analogizing the agency to a jury or a special master and permitting it in admiralty cases to perform the function of the special master." Id. Atlas Roofing did not explain, however, why its characterization of administrative agencies in private rights cases as "only adjuncts" affected Seventh Amendment interpretation. Whether or not the administrative officer in Crowell served as an "adjunct," its findings of fact between private parties were binding on the district court. 285 U.S. at 46.

Moreover, the "adjunct" language in footnote 7 is particularly baffling given that the Court in NLRB v. Jones \& Laughlin Steel Corp., 301 U.S. 1 (1937), validated an administrative adjudication between private parties-union members and their employer-with the administrative order directly enforceable in the courts of appeals.

30. When a court of appeals reviews administrative factfinding, there is, of course, no jury participation. In the less frequent instance when a statute vests jurisdiction in the district courts to review administrative factfinding, the standard of review is not de novo, but is usually that of "substantial evidence," hence precluding jury involvement. See, e.g., Social Security Act of $1935 \S 205(\mathrm{~g}), 42$ U.S.C. $\$ 405(\mathrm{~g})(1982)$ ("The findings of the Secretary as to any fact, if supported by substantial evidence, shall be conclusive...."). 
cated that although a statutory action does not vest a right to jury trial in an administrative setting, the same action may give rise to a jury right if adjudicated in an Article III court. ${ }^{31}$ The Court has justified this inconsistency by asserting that the "right to a jury trial turns not solely on the nature of the issue to be resolved but also on the forum in which it is to be resolved." "32

The Supreme Court's distinction between Article III courts and administrative tribunals in Seventh Amendment interpretation relies on no constitutional principle, but simply reflects a policy of deference to congressionally created procedural schemes. ${ }^{33}$ This deference does not, however, satisfactorily explain why the forum selected by Congress should be relevant to the applicability of the Seventh Amendment, the text of which does not limit itself to Article III courts. ${ }^{34}$ Indeed, because the Framers considered jury trial an important check against the corruption of judges, ${ }^{35}$ it is puzzling that the Court has assumed the Seventh Amend-

31. See Atlas Roofing, 430 U.S. at 455 (Congress may assign adjudication of new statutory "public rights," to administrative agency "even if the Seventh Amendment would have required a jury where the adjudication of those rights is assigned to a federal court of law instead of an administrative agency."); Pernell, 416 U.S. at 383 (Although litigation of landlord-tenant disputes in District of Columbia's court of general jurisdiction triggers Seventh Amendment, "the Seventh Amendment would not be a bar to a congressional effort to entrust landlord-tenant disputes . . . to an administrative agency."); Curtis, 415 U.S. at 195 (Congress may entrust enforcement of statutory rights to administrative agency, "[b]ut when Congress provides for enforcement of statutory rights in an ordinary civil action in the district courts, where there is obviously no functional justification for denying the jury trial right, a jury trial must be available if the action involves rights and remedies of the sort typically enforced in an action at law.") (footnote omitted).

32. Atlas Roofing, 430 U.S. at 461.

33. In holding the Seventh Amendment inapplicable to administrative adjudications, the Supreme Court has relied on the "functional justification" that jury trial would be incompatible with administrative proceedings. Curtis, 415 U.S. at 194-95. Without citing a specific constitutional mandate for its deference to the establishment of nonjury administrative forums, the Court has emphasized congressional discretion to determine the manner in which a statutory right will be enforced. "Congress" power to create legislative courts to adjudicate public rights carries with it the lesser power to create administrative agencies for the same purpose, and to provide for review of those agency decisions in Art. III courts." Northern Pipeline Constr. Co. v. Marathon Pipe Line Co., 458 U.S. 50,67 n.18 (1982) (plurality opinion) (citation omitted).

34. The language of the Seventh Amendment specifies common law suits, not common law courts. Congress approved the Seventh Amendment on September 24, 1789. See 1 ANnals of ConG. 948 (J. Gales ed. 1834). On the same day, Congress enacted the Judiciary Act of 1789, 1 Stat. 73 , establishing a unitary system of federal courts with jurisdiction over both law and equity. This court structure departed from English practice, where courts of law were distinct from courts of equity, and where only law courts afforded jury trial. See J. Friedenthal, M. KANE \& A. Miller, Givil. ProceDURE, 483-84 (1985). Cognizant that common law and equity suits would be entertained by the same courts, Congress must not have believed that the civil jury right in federal courts would hinge on the forum adjudicating "suits at common law." Indeed, Congress must have been wary of the possibility that forum might determine the right to jury trial, for the British use of vice-admiralty courts to deprive colonists of their right to jury trial was one of the most disliked aspects of English rule. See Parklane Hosiery Co. v. Shore, 439 U.S. 322, 340 (1979) (Rehnquist, J., dissenting). Thus, Atlas Roofing's assertion that the right to jury trial depends in part on the forum, see supra text accompanying note 32 , conflicts with the historical concerns surrounding the jury trial guarantee.

35. See, e.g., The Federalist No. 83, at 562 (A. Hamilton) (J. Cooke ed. 1961) (terming trial by jury "a barrier to the tyranny of popular magistrates"); II RECORDS OF THE FEDERAL CONVEN- 
ment to be relevant in Article III courts, where the judges are independent and enjoy life-tenure and salary guarantees, ${ }^{36}$ but irrelevant in nonArticle III tribunals, where the decisionmakers are subject to greater political pressures. ${ }^{37}$ The Court's forum-dependent analysis of the right to civil jury trial has produced the anomalous result that the Article III trial judge may be precluded from determining factual issues in a statutory action where a jury has been demanded, while non-Article III decisionmakers are free to find facts $^{38}$ without the intervention of a jury. ${ }^{38}$

Because the Seventh Amendment refers only to "suits at common law," the Court should interpret the right to jury trial solely according to the "nature" of statutory claims, rather than the forum adjudicating these claims. ${ }^{40}$ If the "nature of the right" is the sole determinant of the Seventh Amendment's applicability, either actions based on congressionally created rights are not common law suits and thus never jury triable of right, or they are suits at common law and therefore jury triable regardless of the forum.

Supporting the former proposition - that statutory actions should not be jury triable under the Seventh Amendment-is language in Supreme Court decisions in the Article III context differentiating statutory actions from suits at common law. Because the Court itself has linked interpretation of the Seventh Amendment with that of Article III, ${ }^{11}$ this distinction is relevant to Seventh Amendment interpretation.

TION, at 587 (M. Farrand, ed. 1937) (Rep. Gerry urging necessity of civil juries to guard against corrupt judges).

36. Article III provides that "[t]he Judges, both of the supreme and inferior Courts, shall hold their Offices during good Behaviour, and shall, at stated Times, receive for their Services a Compensation, which shall not be diminished during their Continuance in Office." U.S. CoNST. art. III, $\$ 1$.

37. For example, although administrative law judges have life tenure, they can be removed "for cause" by their employing agency. 5 U.S.C. $\$ 7521$ (a) (1982). For an assertion that the threat of removal has endangered independent decisionmaking, see Redish \& Marshall, Adjudicatory Independence and the Values of Procedural Due Process, 95 YALE L.J. 455, 499 (1986) (agencies use "the possibility of removal as a tool for coercing decisions that are consistent with the agency's wishes") (footnote omitted).

38. See supra note 20.

39. See, e.g., Reconstruction Fin. Corp. v. Bankers Trust, 318 U.S. 163, 170 (1943) (no jury right in ICC determination of amount owed creditor by bankrupt debtor); NLRB v. Jones \& Laughlin Steel Corp., 301 U.S. 1, 48-49 (1937) (NLRB adjudication to determine whether employer engaged in unfair labor practices does not trigger Seventh Amendment).

40. Although before adoption of the Federal Rules of Civil Procedure, jury trial in Article III courts was often linked to the "side" of the court in which the action was brought, see supra note 13, the nature of the action was the ultimate determinant of the right to jury trial. A litigant could not bring what was essentially a common law action before the equity side of the court in order to avoid jury trial. Cf. Curriden v. Middleton, 232 U.S. 633 (1914) (bill in equity dismissed because plaintiff sought damages, a legal remedy).

41. Justice Story was the first to equate "common law" in the Seventh Amendment with "law" in Article III. See supra notes 10-11 and accompanying text. In Atlas Roofing, the Court assumed that resolution of the Seventh Amendment issue was implicit in its decisions upholding administrative adjudications against Article III challenges. See supra text accompanying notes 25-26. 


\section{Article III Doctrine and the Distinction Between Statutory Actions and Suits at Common Law}

In a long line of decisions addressing the Article III validity of nonArticle III tribunals, the Supreme Court has established that Congress may create both "public" and "private" rights and assign their initial adjudication to forums other than Article III courts. These cases differentiate statutory actions from suits at common law, implying that actions involving congressionally created rights are "cases at law" within the subject matter jurisdiction of Article III courts, but not "suits at common law" within the scope of the Seventh Amendment.

\section{A. The Exemption of Congressionally Created Public and Private Rights from Mandatory Article III Adjudication}

Early challenges to non-Article III tribunals were based on the Article III directive that "[t]he judicial Power shall extend to all Cases in Law and Equity, arising under . . . the Laws of the United States . . . ; to Controversies to which the United States shall be a Party." "42 It was argued that only Article III courts could hear cases arising under federal statutes. ${ }^{43}$ In Murray's Lessee v. Hoboken Land and Improvement Co., ${ }^{44}$ the Court rejected this argument, stating that "matters involving public rights" could be adjudicated in either non-Article III tribunals or Article III courts. ${ }^{45}$ Although not specifically defining "matters involving public rights," $" 48$ the Court distinguished such matters from suits at common law

42. U.S. Const. art. III, $\S 2$.

43. See, e.g., Reconstruction Fin. Corp. v. Bankers Trust, 318 U.S. 163, 168 (1942) (argument that "by Art. III, § 1, the judicial power of the United States is vested exclusively in the courts and matters of private right may not be relegated to administrative bodies for trial"); Murray's Lessee v. Hoboken Land and Improvement Co., 59 U.S. (18 How.) 272, 275 (1855) (claim that auditing of accounts and issuance of warrant by Treasury Department is unconstitutional "exercise of the judicial power of the United States").

44. 59 U.S. (18 How.) 272 (1855).

45. Justice Curtis wrote for the Court:

[T]here are matters, involving public rights, which may be presented in such form that the judicial power is capable of acting on them, and which are susceptible of judicial determination, but which congress may or may not bring within the cognizance of the courts of the United States, as it may deem proper. Id. at 284.

That Article III permits Congress to assign the enforcement of public rights to non-Article III tribunals was restated in Northern Pipeline Constr. Co. v. Marathon Pipe Line Co., 458 U.S. 50, 70 (1982) (plurality opinion) ("Our precedents clearly establish that . . . [public rights cases] may be removed from Art. III courts and delegated to legislative courts or administrative agencies for their determination.")

Although "public rights" cases are constitutionally assignable to non-Article III forums, Congress usually provides a statutory right of appeal to Article III courts. See 29 U.S.C. $\$$ 660(a) (1982) (providing review in U.S. Courts of Appeals of Occupational Safety and Health Commission orders); J. MASHAw \& R. MeRRILL, supra note 20, at 688 ("Language in federal statutes purporting to bat judicial review of final administrative decisions is sparse.") (emphasis in original).

46. As an illustration of matters involving public rights, the Court cited equitable claims to land 
which require adjudication in Article III courts. ${ }^{47}$ Atlas Roofing's reliance on the public rights concept in exempting administrative adjudications from the Seventh Amendment ${ }^{48}$ therefore accords with established Article III doctrine indicating that public rights cases are not suits at common law. ${ }^{49}$

Atlas Roofing characterized the Court's Article III cases as upholding administrative factfinding only when "the Government is involved in its sovereign capacity under an otherwise valid statute creating enforceable public rights." ${ }^{100}$ Notwithstanding the Court's claim in Atlas Roofing that "[w]holly private tort, contract, and property càses, as well as a vast range of other cases" could not be the subject of administrative factfinding, ${ }^{\text {s1 }}$ the Court's exemption of statutory actions from de novo factfinding in Article III courts has not been confined to matters in which the government has litigated in its sovereign capacity.

The Court has on several occasions validated non-Article III adjudications between private parties. ${ }^{32}$ For example, in Crowell v. Ben-

by the inhabitants of ceded territories. Murray's Lessee, 59 U.S. at 284. Because this example is one in which the government is a defendant, the "public rights" exception could arguably be limited to suits against the sovereign. It appears, however, that the Court did not intend such a limitation, for it recognized the conclusive nature of an executive decision in "a suit between private persons to try a question of private right" where the Constitution or laws committed the matter to the executive. Id. at 284-85.

After Murray's Lessee, the Court defined suits involving "public rights" as those arising "between the Government and persons subject to its authority in connection with the performance of the constitutional functions of the executive or legislative departments." Crowell, 285 U.S. at 50, quoted in Northern Pipeline, 458 U.S. at 67-68 (plurality opinion).

The definition of public rights disputes as, "at a minimum," arising "between the government and others," "Northern Pipeline, 458 U.S. at 69 (plurality opinion), quoting Ex Parte Bakelite Corp., 279 U.S. 438, 451 (1929), has recently been eroded. See Thomas v. Union Carbide, 105 S. Ct. 3325, 3337 (1985) (indicating that statutory right of private parties has "public right" characteristics); see also infra notes 63-71 and accompanying text.

47. The Court suggested that Congress could not withdraw from Article III courts "any matter which, from its nature, is the subject of a suit at the common law, or in equity, or admiralty." 59 U.S. (18 How.) at 284.

48. 430 U.S. at 450. In employing the Article III "public rights" doctrine to determine the Seventh Amendment's applicability to administrative adjudications, the Court ignored the legal-equitable dichotomy that had long served as the means of analyzing the right to civil jury trial. See supra note 13. The Court explicitly rejected the argument that its validation of the administrative adjudication in NLRB v. Jones \& Laughlin Steel Corp., 301 U.S. 1 (1937), see infra note 77, was premised on the equitable nature of the NLRB proceeding. 430 U.S. at 455.

49. Atlas Roofing's conclusion, however, that the right to civil jury trial in actions involving public rights is dependent upon the forum contradicts earlier assumptions in Article III doctrine that congressional choice of forum does not change the nature of public rights actions. See Glidden Co. v. Zdanok, 370 U.S. 530, 572 (1962) (plurality opinion) (noting legitimacy of nonjury mode of trial in Court of Claims depended not on "legislative" character of court, but on fact that suits against Government are not "suits at common law" within meaning of Seventh Amendment); see also P. BATOR, P. Mishinin, D. Shapiro \& H. Wechsler, Hart \& Wechsler's The Federal Courts and THE FEDERAL SYSTEM 399 (2d ed. 1973) (approving reasoning in Glidden plurality opinion).

50. 430 U.S. at 458 .

51. Id.

52. E.g., Thomas v. Union Carbide, 105 S. Ct. 3325 (1985) (compensation dispute among pesticide manufacturers settled by binding arbitration); Reconstruction Fin. Corp. v. Bankers Trust, 318 
son, ${ }^{53}$ a case involving administrative adjudication of workers' compensation claims, the Court assumed that while Article III judges have de novo review over questions of law in statutory "private right" cases, questions of fact in such cases may be finally determined by non-Article III tribunals. $^{54}$

\section{B. Mandatory Article III Adjudication of Rights Not Congressionally Created}

While determining whether statutory "public" and "private" rights cases may be assigned to non-Article III forums, the Supreme Court in recent decisions has attempted to define those matters requiring adjudication in Article III courts. In Northern Pipeline Construction Co. v. Marathon Pipe Line Co., ${ }^{\text {ss }}$ the power of a U.S. Bankruptcy Court (a nonArticle III legislative court) to exercise jurisdiction over a state law contract claim was challenged on Article III grounds. ${ }^{56}$ The plurality declined to validate the bankruptcy court's jurisdiction on a "public rights" theory, stating that "only controversies [in which the government is a party] . . . may be removed from Art[icle] III courts."

Furthermore, the plurality distinguished constitutional and state law rights from those created by Congress, ${ }^{58}$ terming the adjudication of the former an "essential attribute of the judicial power" reserved to Article III courts. ${ }^{58}$ In Crowell, the Court had identified "cases brought to enforce constitutional rights" as requiring determination of both law and facts by an Article III court. ${ }^{\circ 0}$ Drawing on Crowell's distinction between congres-

U.S. 163 (1943) (amount owed creditor by bankrupt debtor determined by ICC); NLRB v. Jones \& Laughlin Steel Corp., 301 U.S. 1 (1937) (union members' claim against employer for restoration to service and backpay adjudicated by NLRB); Crowell v. Benson, 285 U.S. 22 (1932) (worker's compensation claim against employer for injuries reviewed by U.S. Employees' Compensation Comm'n); Block v. Hirsh, 256 U.S. 135 (1920) (landlord's suit against tenant for possession adjudicated by legislative commission).

53. 285 U.S. 22 (1932).

54. Id. at 51. ("But in cases of . . [private right], there is no requirement that, in order to maintain the essential attributes of the judicial power, all determinations of fact in constitutional courts shall be made by judges."); see also Hart, The Power of Congress to Limit the Jurisdiction of Federal Courts: An Exercise in Dialectic, 66 HARv. L. REv. 1362, 1375 (1953) (characterizing Crowell as holding that "administrative findings of non-constitutional and non-jurisdictional facts may" be made conclusive upon the courts, if not infected with any error of law, as a basis for judicial enforcement of a money liability of one private person to another").

55. 458 U.S. 50 (1982).

56. The statute invalidated by the Court established Article I bankruptcy court jurisdiction over "all civil proceedings arising under Title 11 or arising in or related to cases under Title 11." 28 U.S.C. \& 1471(b) (1978).

57. 458 U.S. at 70 (plurality opinion) (emphasis in original). This definition of "public rights" was rejected in Thomas v. Union Carbide, 105 S. Ct. 3325 (1985). See infra notes 69-70 and accompanying text.

58. 458 U.S. at 83-84 (plurality opinion).

59. Id. at 81 (plurality opinion).

60. 285 U.S. at 60 . Crowell also stated that administrative determinations of "jurisdictional facts" 
sionally created rights and constitutional rights, the Northern Pipeline plurality in effect analogized "rights created by state law" to "constitutional rights," $"$ and held that the contract claim required factual determination in an Article III court. The Northern Pipeline Court, however, emphasized that Congress can exercise substantial discretion in assigning the initial adjudication of cases involving congressionally created federal rights to administrative tribunals. ${ }^{62}$

Following Northern Pipeline, a unanimous Court in Thomas v. Union Carbide ${ }^{63}$ specifically approved Congress' assignment of private statutory actions to a non-Article III forum. Challenged in Union Carbide was a provision of the Federal Insecticide, Fungicide, and Rodenticide Act (FIFRA) ${ }^{64}$ establishing a system of negotiation and binding arbitration to resolve compensation disputes among pesticide registrants. ${ }^{65}$ The appellees disputed the Article III validity of the arbitration provision ${ }^{68}$ on the basis

are subject to de novo review by Article III courts. The Court characterized "jurisdictional facts" as those that establish the "condition precedent to the operation of the statutory scheme." Id. at 54 . The jurisdictional fact to be determined in Crowell was whether the worker's injury occurred upon navigable waters, a prerequisite for claims brought under the Longshoremen's and Harbor Workers' Act. Id. at 55-56.

The Court has effectively abandoned the Crowell requirement that administrative determinations of "constitutional" and "jurisdictional" facts be subject to de novo judicial review. See Northern Pipeline Constr. Co. v. Marathon Pipe Line Co., 458 U.S. 50, 82 n.34 (1982) ("Crowell's precise holding, with respect to the review of 'jurisdictional' and 'constitutional' facts that arise within ordinary administrative proceedings, has been undermined by later cases."); 5 K. DAvis, AdMINISTRative LAW TREATISE, 441 (2d ed. 1984) (noting Crowell's jurisdictional and constitutional fact doctrine has not been expanded).

61. 458 U.S. at 83-84. Although the plurality questioned the vitality of Crowell's "constitutional fact" doctrine, see supra note 60, it stated that "the general principle of Crowell-distinguishing between congressionally created rights and constitutionally recognized rights-remains valid." 458 U.S. at 82 n.34. That is, non-Article III courts could perform conclusive factfinding in actions involving congressionally created rights, but not in actions involving constitutional rights.

By the plurality's reasoning, "rights created by state law" are analogous to "constitutional rights" in that neither are created by Congress. Because the contract claim at issue was not based on a right of congressional creation, the plurality held that no justification existed for its adjudication in a nonArticle III forum. 458 U.S. at 83-84 (plurality opinion).

62. See, e.g., 458 U.S. at 83 (plurality opinion) (footnote omitted):

But when Congress creates a statutory right, it clearly has the discretion, in defining that right, to create presumptions, or assign burdens of proof, or prescribe remedies; it may also provide that persons seeking to vindicate that right must do so before particularized tribunals created to perform the specialized adjudicative tasks related to that right. Such provisions . . . are also incidental to Congress' power to define the right it has created.

63. 105 S. Ct. 3325 (1985).

64. 7 U.S.C. $\S 136 \mathrm{a}(\mathrm{C})(1)(\mathrm{D})(\mathrm{ii})(1982)$.

65. FIFRA authorizes the Environmental Protection Agency to utilize research data submitted in a registration application by a pesticide manufacturer (original registrant) when evaluating the subsequent application of another manufacturer (follow-on registrant). The follow-on registrant is required to compensate the original registrant for use of the data; absent agreement on the compensation amount, the registrants are obliged to submit to binding arbitration.

The findings and determination of the arbitrator are "final and conclusive" and are not reviewable in an Article III court "except for fraud, misrepresentation, or other misconduct by one of the parties to the arbitration or the arbitrator." Id. $\S 136 \mathrm{a}(\mathrm{c})(1)(\mathrm{D})(\mathrm{ii})(1982)$.

66. The appellees argued "that Article III bars Congress from requiring arbitration of disputes ... under FIFRA without also affording substantial review by tenured judges of the arbitrator's 
of Northern Pipeline, arguing both that FIFRA confers a "private right" to compensation and that the right to compensation is a state law right. ${ }^{67}$

The Court disagreed with appellee's characterization of the compensation claim as a matter of state law, declaring that the compensation right was congressionally created. ${ }^{68}$ Rejecting appellee's contention that Northern Pipeline required either "Article III adjudication or review by an Article III court" because the FIFRA compensation dispute did not involve the government as a party, the Court stressed that "the identity of the parties alone" does not determine "the requirements of Article III."70 In holding the arbitration provision compatible with Article III, the Court described the right created by FIFRA as a "private" right bearing "many of the characteristics of a 'public' right."'71

With Union Carbide's blurring of the distinction between "public" and "private" rights, and Northern Pipeline's language supporting broad congressional discretion to determine the procedural means of enforcing federal statutory rights, there appears to be no Article III limitation on the kind of federal statutory actions that Congress may create and assign to non-Article III forums for factfinding. ${ }^{72}$

\section{The Tension Between Forum-Dependency and Article III Doctrine}

The forum-dependent interpretation of the Seventh Amendment articulated in Atlas Roofing, Curtis, and Pernell-that statutory actions are "susceptible of judicial determination" in either non-Article III forums

decision." 105 S. Ct. at 3334.

67. Id. at 3335

68. Id. ("Any right to compensation ... results from FIFRA and does not depend on or replace a right to such compensation under state law.").

69. Id. at 3335 .

70. Id. at 3337. The Court did not accept appellec's argument that Northern Pipeline and Crowell established the absolute "right to an Article III forum . . . unless the federal government is a party of record." Id. at 3336. Justice Brennan, author of the plurality opinion in Northern Pipeline, concurred in Union Carbide, agreeing that "the presence or absence of the government as a party" was not the "determinative factor" with respect to the statutory scheme's Article III validity. Id. at 3342. While admitting that the FIFRA compensation dispute was "private," Justice Brennan described the statutory scheme "as involving a matter of public rights." Id. at 3343.

71. Id. at 3337 .

72. After recognizing that administrative "adjuncts" may find facts in actions involving congressionally created rights, the Northern Pipeline plurality stated, "[t]hese cases do not require us to specify further any limitations that may exist with respect to Congress' power to create adjuncts to assist in the adjudication of federal statutory rights." 458 U.S. at 80 n.32.

Left unanswered by Northern Pipeline and Union Carbide is the extent to which Article III courts must retain review over questions of law in statutory actions assigned to non-Article III forums. The statutory scheme validated in Union Carbide allowed judicial review of the arbitrator's decision only in the event of fraud, misrepresentation, or other misconduct. 7 U.S.C. $\S 136 \mathrm{a}$ (c)(1)(D)(ii) (1982). While the Court's opinion characterized this as "limited Article III review," 105 S.Ct. at 3339, Justice Brennan claimed that "[s]uch review preserves the judicial authority over questions of law in the present context." Id. at 3344 (Brennan, J., concurring).

73. Murray's Lessee, 59 U.S. (18 How.) at 284. 
or Article III courts but definable as common law suits only in the latter ${ }^{44}$-conflicts with the Court's Article III jurisprudence.

The line of cases from Murray's Lessee to Union Carbide establishes that Congress may assign actions based on statutory rights to non-Article III forums. At the same time, these decisions presuppose that suits at common law must be tried, both as to law and to fact, in Article III courts. ${ }^{75}$ That actions based on congressionally created rights do not require de novo adjudication by Article III courts ${ }^{76}$ suggests that the Court's Article III jurisprudence does not admit the possibility that statutory actions are definable as suits at common law. ${ }^{77}$

\section{Proposed Analysis of the Applicability of the Seventh Amendment to Federal Statutory Actions}

Article III doctrine calls into question the continued validity of Justice Story's claim that "law" in Article III and "common law" in the Seventh Amendment are synonymous. The logical conclusion of Story's assertion is that all "cases at law" under Article III are "suits at common law" within the scope of the Seventh Amendment. But in permitting statutory actions that are "cases at law" in an Article III court to be heard in non-Article III tribunals without a jury, the Supreme Court has rejected any notion that "suits at common law" exhaust the category of "cases at law."

The "suits at common law" language of the Seventh Amendment

74. See supra note 31 and accompanying text.

75. In Murray's Lessee, the Court remarked, "we think it proper to state that we do not consider congress can . . . withdraw from judicial cognizance any matter which, from its nature, is the subject of a suit at the common law or in equity, or admiralty." 59 U.S. (18 How.) at 284. The plurality in Northern Pipeline held the state law contract claim at issue required adjudication in an Article III court. 458 U.S. at 63-87. This holding has been interpreted to mean that common law suits must be heard in Article III courts. See, e.g., id. at 90 (Rehnquist, J., concurring in judgment) (Article III courts must adjudicate claims "which are the stuff of the traditional actions at common law tried by the courts at Westminster in 1789"); id. at 92 (Burger, C.J., dissenting) (stating Court's holding as requiring adjudication in Article III court of " 'traditional' state common-law action, not made subject to a federal rule of decision"); Monaghan, Marbury and the Administrative State, 83 Colum. L. REv. 1, 18 (1983) ("It appears, therefore, that common law rights must generally be litigated in either article III or state courts . . . ."); see also Union Carbide, 105 S. Ct. at 3336 ("matters subject to a 'suit at common law or in equity or admiralty' are at 'protected core' of Article III judicial powers") (paraphrasing Northern Pipeline plurality opinion, 458 U.S. at 70-71 \& n.25).

76. Congress may be required to provide for Article III judicial review of administrative adjudications, Northern Pipeline, 458 U.S. at 69-70 n.23, citing Atlas Roofing, 430 U.S. at 455 n.13, but review on questions of fact is not de novo. See supra note 20.

77. The Court's language in NLRB v. Jones \& Laughlin Steel Corp., 301 U.S. 1 (1937), upholding a NLRB adjudication against Article III and Seventh Amendment challenges, demonstrates this distinction: "The instant case is not a suit at common law or in the nature of such a suit. The proceeding is one unknown to the common law. It is a statutory proceeding." Id. at 48. Significantly, the Jones \& Laughlin Court did not mention forum as a factor in its holding, nor did it characterize the statutory action as equitable. The statutory action was deemed sui generis. See Comment, The Seventh Amendment and Civil Rights Statutes: History Adrift in a Maelstrom, 68 Nw. U.L. REv. $503,527-28$ (1973) (noting that Jones $\mathfrak{E}^{\circ}$ Laughlin did not analogize statutory proceeding to equity in order to hold Seventh Amendment inapplicable). 
should be read to exclude plainly statutory actions. The Court's consistent recognition that factfinding in statutory actions may occur in either Article III courts or non-Article III tribunals can be reconciled with the Seventh Amendment only if the amendment is in fact inapplicable to suits involving congressionally created rights heard in the federal district courts. The proposition that statutory actions are not jury triable of right must, however, be applied so as not to encroach upon the right to jury trial of actions legitimately within the scope of the Seventh Amendment.

\section{A. Distinguishing Congressionally Created Rights from Common Law Rights}

The proposed exemption of federal statutory actions from the Seventh Amendment must be qualified to account for instances in which the statutory action merely codifies a constitutional or state law right requiring de novo factfinding by an Article III court. ${ }^{78}$ If this constitutional or state law right was known at common law, the right to trial by jury must be preserved.

A statutory right constitutionally enforceable in a non-Article III tribunal is, by definition, neither a constitutional nor a state law right, ${ }^{79}$ and by implication, not a common law right. ${ }^{80}$ An action in a non-Article III tribunal is therefore appropriately outside the scope of the Seventh Amendment. ${ }^{81}$ A statutory cause of action in federal district court, on the other hand, may be either congressionally created or based on a preexisting constitutional or state law right. Insofar as the substantive right has been congressionally created, and thus assigned for enforcement to federal district courts as a matter of congressional discretion, ${ }^{82}$ the legal or equitable nature of the right should be as irrelevant in the Article III court as it is in a non-Article III tribunal. Such an action should not fall within the scope of the Seventh Amendment.

If, however, an action authorized by a federal statute merely codifies a constitutional or state law right, ${ }^{\mathbf{8 3}}$ only an Article III court may adjudicate

78. An action may be authorized by statute but originate from a constitutional or state law right. This was the situation in Northern Pipeline-the federal bankruptcy statute permitted the bankruptcy court to exercise jurisdiction over "civil proceedings . . . related to cases under title 11," 28 U.S.C. $\S 1471$ (b) (1982), which included jurisdiction over the state law contract claim. 458 U.S. at 56 . But see Union Carbide, $105 \mathrm{~S}$. Ct. at 3335, rejecting appellee's contention that compensation claims "under FIFRA are a matter of state law."

79. See supra notes 58-62 and accompanying text.

80. See supra notes $75-77$ and accompanying text.

81. A negative answer to the Article III inquiry would always resolve the Seventh Amendment issue-if Article III does not require adjudication of the action in an Article III tribunal, the action cannot be a "suit at common law" for Seventh Amendment purposes.

82. That is, Article III would not require that only Article III courts perform de novo factfinding in such an action. See supra notes 55-72 and accompanying text.

83. See supra note 78 . 
the matter. Because such an action is not congressionally created, analysis of its legal or equitable nature appropriately determines the applicability of the Seventh Amendment. ${ }^{84}$

For example, if Congress passed a uniform federal products liability law, ${ }^{85}$ thereby preempting state law, a district court judge resolving a Seventh Amendment claim in an action based on the statute would: 1) determine whether the action was based on a congressionally created right or a preexisting state law right requiring adjudication in an Article III court; and, if the latter, 2) analyze the claim as to its legal or equitable nature. With this analysis, the products liability action would be jury triable under the Seventh Amendment. First, the state law right to sue manufacturers on a theory of products liability existed before the hypothetical congressional enactment. Northern Pipeline implies that a non-Article III court would be constitutionally prohibited from adjudicating such a statutory products liability claim. Second, products liability actions are tort suits and thus indisputably "suits at common law."

A private antitrust action under the Clayton $\mathrm{Act}^{\mathrm{8}}$ exemplifies those statutory actions that should be outside the scope of the Seventh Amendment. A district court judge analyzing the right to trial by jury in a federal antitrust action would inquire whether Congress, in enacting the antitrust laws, created new rights constitutionally enforceable in either Article III courts or non-Article III tribunals. ${ }^{87} \mathrm{~A}$ determination that the cause of action was congressionally created would resolve the Seventh Amendment issue-the action would not be jury triable of right.

84. This assumes that the state law right is not a state statutory right. If a state statutory right is at issue, the simple proposition that statutory law is not common law would suggest that the Seventh Amendment should not apply. The argument of this Note, however, is that the Seventh Amendment should not apply to federal statutory actions.

85. Congress is currently considering uniform products liability legislation. See e.g., S. 100, 99th Cong., 1st Sess., 131 Cong. Rec. S218 (daily ed. Jan. 3, 1985).

86. Section 4 of the Clayton Act, 15 U.S.C. $§ 15(a)$ (1982) provides that:

[A]ny person who shall be injured in his business or property by reason of anything forbidden in the antitrust laws may sue therefor in any district court of the United States . . . without respect to the amount in controversy, and shall recover threefold the damages by him sustained, and the cost of suit, including a reasonable attorney's fee.

The Supreme Court has indicated that the Seventh Amendment extends to actions under the federal antitrust laws. Beacon Theatres, Inc. v. Westover, 359 U.S. 500, 504 (1959) ("[T]he right to trial by jury applies to treble damage suits under the antitrust laws.").

87. Most commentators agree that neither Article III nor the Seventh Amendment would bar adjudication of antitrust actions in non-Article III courts. See, e.g., Edquist, The Use of Juries in Complex Cases, 3 CoRp. L. REv. 277, 298 (1980) (Congress could provide enforcement of antitrust actions in administrative tribunals.); Jorde, The Seventh Amendment Right to Jury Trial of Antitrust Issues, 69 CaLIF. L. REV. 1, 21 (1981) (same). 


\section{B. Operation of the Suggested Rule}

That the Seventh Amendment should not apply to substantive causes of action created by Congress does not mean that all statutory actions would be tried without juries. Federal Rule of Civil Procedure 38(a) ${ }^{88}$ reserves congressional power to confer a jury right by statute in actions not within the scope of the Seventh Amendment. Thus, Congress may provide for the availability of jury trial in a statutorily created action, but need not do so.

There are several reasons why Congress might refrain from conferring a jury right in a new cause of action. Congress might prefer factfinding by judges rather than by juries because it considers judges more capable of applying statutes uniformly or understanding the often complex facts associated with statutory actions. ${ }^{89}$ Furthermore, a nonjury Article III forum ${ }^{90}$ would offer Congress an alternative either to using existing administrative tribunals and legislative courts that are already highly specialized, or to creating and funding new tribunals.

When a suit presents both statutory and legal claims based on the same factual predicate, a jury trial should be guaranteed, by analogy to the rule that legal claims may not lose their entitlement to jury trial by prior determination of equitable claims. ${ }^{91}$ The district court could, however, exercise its power to order separate trials of any claims or issues. ${ }^{92}$ In this

88. "The right of trial by jury as declared by the Seventh Amendment to the Constitution or as given by a statute of the United States shall be preserved to the parties inviolate." FED. R. Grv. P. 38(a).

89. Many commentators have argued that current Supreme Court jurisprudence on the right to civil jury trial is incompatible with the increasing complexity of civil cases and have suggested a complexity exception to the Seventh Amendment. See, e.g., Oakes, The Right to Strike the Jury Trial Demand in Complex Litigation, 34 U. Mismi L. Rev. 243 (1980) (due process compels that judge deny litigant's jury demand if case too complex); Note, The Right to a Jury Trial in Complex Civil Litigation, 92 HARv. L. REv. 898 (1979) (court has power to declare issues equitable if suit too complex for jury). Others have argued that new statutory actions should be declared equitable and therefore outside the reach of the Seventh Amendment. See, e.g., Note, Congressional Provision for Nonjury Trial Under the Seventh Amendment, 83 YALE L.J. 401 (1973) (congressional mandate that statutory action be tried to judge alone indicates action is equitable).

90. The Supreme Court has not yet considered whether a federal statute providing for nonjury trial of a statutory action in the district courts conforms with the Seventh Amendment. In the Foreign Sovereign Immunities Act, 28 U.S.C. $§ 1330$ (1982), Congress granted subject matter jurisdiction to the federal courts to hear claims against foreign governments or their instrumentalities. The Act limits jurisdiction to "nonjury civil action[s]." 28 U.S.C. $\S 1330$ (a). Four circuits have upheld the Act against Seventh Amendment challenge. Goar v. Gia. Peruana de Vapores, 688 F.2d 417 (5th Cir. 1982); Rex v. Cia. Pervana de Vapores, 660 F.2d 61 (3d Cir. 1981), cert. denied, 456 U.S. 926 (1982); Williams v. Shipping Corp. of India, 653 F.2d 875 (4th Cir. 1981), cert. denied, 455 U.S. 982 (1982); Ruggiero v. Cia. Peruana de Vapores, 639 F.2d 872 (2d Cir. 1981).

91. See Beacon Theatres v. Westover, 359 U.S. 500, 511 (1959) (stressing "the right to a jury trial of legal issues [may not] be lost through prior determination of equitable claims"); see also Dairy Queen, Inc. v. Wood, 369 U.S. 469,479 (1962) (when equitable and legal claims share common factual issues, legal claim must be tried first to jury, despite fact that main claim seeks equitable relief.

92. The Federal Rules of Civil Procedure provide that "[t]he court . . . may order a separate trial of any claim ... or of any separate issue or of any number of claims . . or issues, always 
situation, if the statutory claim is tried first, the court's adjudication of factual issues common to the legal and statutory claims should be given res judicata or collateral estoppel effect with respect to the legal claim. ${ }^{93}$

\section{ConCLUSION}

The rule proposed by this Note, that statutory actions in the district courts not be jury triable of right, applies only to substantive causes of action created by Congress-actions that could be adjudicated in nonArticle III tribunals-and hence does not circumvent the Seventh Amendment. Until the Supreme Court fixes a limitation on the sorts of statutorily created rights that may be enforced in non-Article III tribunals without juries, the proposed rule would pose no greater inroad on the Seventh Amendment than that which already exists. By holding the civil jury right inapplicable to federal statutory actions, the Supreme Court can add clarity and consistency to Seventh Amendment interpretation.

preserving inviolate the right of trial by jury as declared by the Seventh Amendment to the Constitution or as given by a statute of the United States." FED. R. Civ. P. 42(b).

93. This is consistent with Parklane Hosiery Co. v. Shore, 439 U.S. 322 (1979), holding that the law of collateral estoppel prevented a party from relitigating in a legal action issues of fact adjudicated adversely to it in a prior equitable action. The Court found that such an application of collateral estoppel did not violate the Seventh Amendment.

Currently, federal courts will give res judicata and collateral estoppel effect to prior administrative decisions. See generally 5 B. Mezines, J. Stein \& J. Gruff, Administrative Law $\$ 40.01$ (1985) (discussing preclusion effects of administrative determinations). 